http://ejournal.undip.ac.id/index.php/kapal

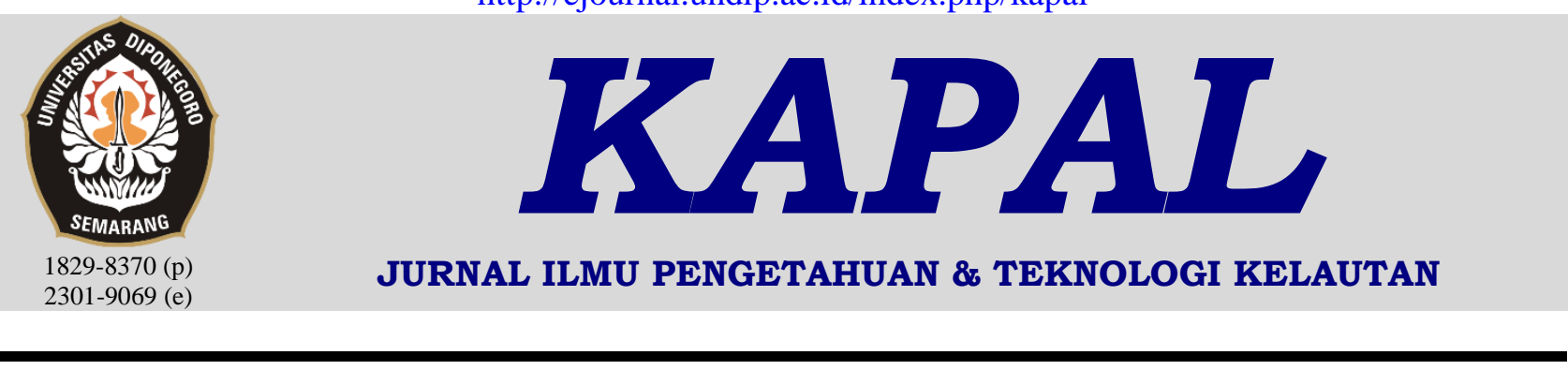

\title{
Penentuan Ukuran Utama dan Rencana Garis Fast Ferry 150 Pax Untuk Penyeberangan Rute Gresik - Bawean
}

\author{
Budianto $^{l) *}$ \\ ${ }^{1)}$ Teknik Desain dan Konstruksi Kapal, Politeknik Perkapalan Negeri Surabaya, Indonesia \\ Jl. Teknik Kimia, Kampus ITS, Keputih, Sukolilo, Surabaya, Indonesia 60111
}

\begin{abstract}
Abstrak
Transportasi laut memiliki peranan penting dalam distribusi sumber-sumber utama kebutuhan pokok masyarakat, hasil pertanian dan transportasi penyeberangan di Pulau Bawean. Fast Ferry 150 Pax merupakan solusi tepat untuk transportasi laut penyeberangan rute Gresik-Bawean, yangmana memiliki kecepatan lebih cepat dibanding dengan kapal RO-RO ataupun Kapal Ferry yang ada. Untuk membangun Sebuah Fast Ferry 150 Pax diperlukan basic design yang baik, dimana salah satunya dalam perancangan ukuran utama kapal dengan metode kapal pembanding dan penentuan desain rencana garis. Penentuan ukuran utama kapal merupakan rencana kunci dalam perancangan kapal Fast Ferry 150 Pax dengan memperhatikan regulasi dari Klasifikasi dan standar mendasain keselamatan kapal dalam beroperasional dilaut. Dimana dalam menentukan ukuran utama dan lineplan (rencana garis) tersebut meliputi beberapa perancangan antara lain: menetukan ukuran utama kapal, menentukan desain kapal pembanding, membuat CSA dan shape control body plan. Dalam desain Fast Ferry 150 Pax, diharapkan ketelitian yang lebih fokus dalam mencakup aspek regulasi dan keselamatan dalam kelaik-lautan kapal tersebut. Dimana didapatkan desain kapal Fast ferry 150 Pax tersebut dengan ukuran utama kapal LOA 35.00 m, lebar 5.50 m, tinggi 2.00 m, Sarat 1.08 m dan memiliki kapasitas penumpang 150 orang.
\end{abstract}

Copyright @ 2017, KAPAL, 1829-8370(p), 2301-9069(e)

Kata Kunci : Ukuran utama, Metode kapal pembanding, Fast ferry

\section{PENDAHULAN}

Alat transportasi yang berkaitan erat dengan laut diantaranya adalah kapal laut. Kapal laut merupakan sarana transportasi yang penting dan terjangkau dalam aktivitas hubungan antara masyarakat dari pulau satu dengan pulau yang lainnya. Kondisi geografis Kepulauan Bawean yang dapat diterapkan menggunakan transportasi laut menuju Kabupaten Gresik, Indonesia. Transportasi laut tersebut memiliki peranan penting dalam distribusi sumber-sumber utama kebutuhan pokok masyarakat, hasil pertanian dan transportasi penyeberangan di Pulau Bawean. Dengan memanfaatkan transportasi laut sehingga dapat mensejahterakan masyarakat khususnya untuk pendistribusian kebutuhan bahan pokok,

*) Penulis Korespondensi :

Email : budianto.struture@gmail.com hasil pertanian dan transortasi laut. Transportasi laut biasanya berupa kapal RO-RO, Ferry, LCT, dan lain-lain.

Pulau Bawean merupakan pulau yang terletak di kawasan Laut Jawa, sekitar berjarak 80 Mil atau 120 kilometer sebelah utara Kabupaten Gresik. Dapat ditunjukan pada gambar 1. Wilayah Pulau Bawean. Dimana dapat berpotensi untuk dikembangkan sarana fasilitas transportasi laut, untuk mempermudah akses mobilitas dan distribusi bahan pokok.

Dimana pulau Bawean kondisi secara administratif kependudukan semenjak tahun 1974, pulau ini termasuk dalam wilayah Kabupaten Gresik, Provinsi Jawa Timur. Pulau Bawean memiliki 2 Kecamatan yaitu Kecamatan Tambak dan Kecamatan Sangkapura. Jumlah penduduk mencapai sekitar 70.000 Jiwa. Disamping itu, juga memiliki sebuah pelabuhan di Sangkapura untuk 
bersandarnya kapal, yang merupakan transportasi laut untuk satu-satunya akses yang bisa menuju ke Pulau Bawean.

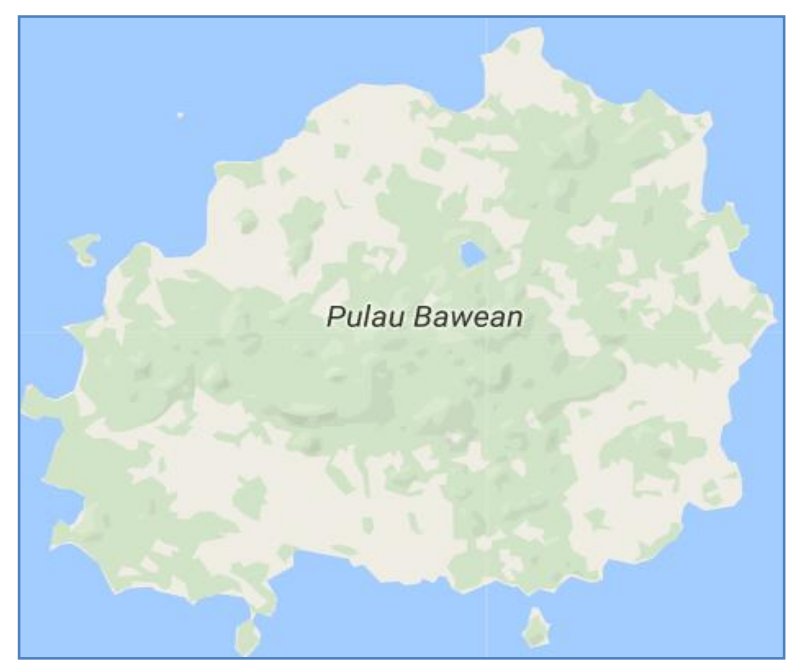

Gambar 1. Wilayah Pulau Bawean

Dalam sehari-hari, keberangkatan dari dan menuju ke Pulau Bawean hanya sekali dan dapat di tempuh dengan waktu kurang lebih 8 jam penyeberangan tergantung dari kecepatan maksimal kapal yang di tempuh dan kondisi cuaca. Kendala dalam kapal adalah cuaca buruk dan gelombang tinggi adalah Faktor utama yang menjadi penentu jadwal pelayaran dan pengiriman Sejumlah kebutuhan pokok untuk Masyarakat Bawean dapat tertunda. Keberangkatan kapal Bawean-Gresik terlebih dahulu harus selalu memperhatikan informasi cuaca maritim atau peringatan dini (warning) dari $\mathrm{BMKG}$, terutama pada musim gelombang tinggi dan angin kencang. Syahbandar Gresik akan menunda keberangkatan kapal, apabila ada peringatan dini yang menyebutkan adanya cuaca ekstrim dan cukup signifikan menggangu keselamatan pelayaran. Sehingga diperlukan peranan yang baik untuk mempersingkat jarak tempuh yang ada dengan melakukan optimasi perancangan Fast Ferry 150 Pax, yang sebelumnya hanya dilakukan studi kelayakan kapal fery angkutan orang dan barang. Sehingga hal itu perlu kelanjutan untuk sarana transportasi laut di Pulau Bawean - Gresik, dalam penentuan ukuran utama dan rencana garis Fast ferry 150 Pax yang efektif dan efisien.

Kapal Ferry merupakan jenis kapal yang digunakan untuk penyebrangan laut yang dapat mengangkut penumpang dan kendaraannya. Kendaraan yang diangkutpun, bisa berupa mobil pribadi, ataupun kendaraan bermotor. Hal yang membuat penggunaan kapal ini adalah tidak adanya jembatan penyebrangan laut. Biasaya kapal ferry hanya memiliki satu buah pintu rampa untuk akses keluar masuk kendaraan, berbeda dengan kapal RO-RO yang memiliki dua buah pintu masuk, dari depan dan belakang kapal. Sehingga bentuk kapal RO-RO memiliki bentuk dimesi yang lebih besar dibandingkan kapal ferry. Adapun kapal fast ferry dikembangkan dengan kecepatan tinggi, sehingga khusus untuk mengangkut penupang dan barang terbatas [6].

Berikut ditunjukan gambar 2. Kapal RO-RO, dimana memiliki dua buah pintu rampa yang berada didepan dan belakang.

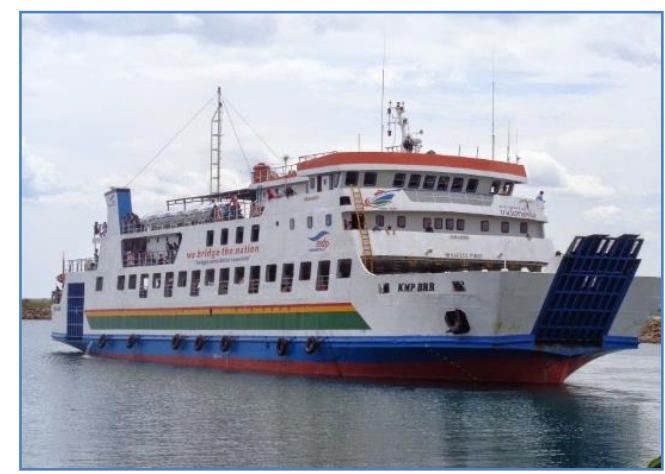

Gambar 2. Kapal RO-RO

Dibawah ini ditunjukan gambar 3. Kapal Ferry, dimana pada dasarnya digunakan untuk agkutan orang dan barang, dimana pintu rampa umumnya berada pada belakang kapal.

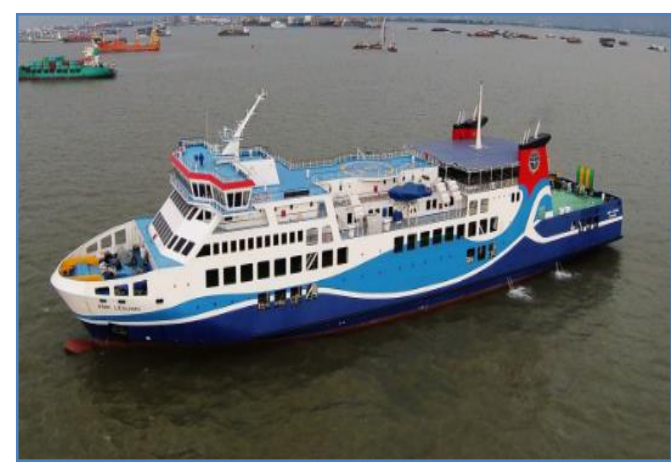

Gambar 3. Kapal Ferry

Berikut ditunjukan gambar 4. Kapal Fast Ferry, dimana pada umumnya bentuk lambung kapal relative lebih ramping.

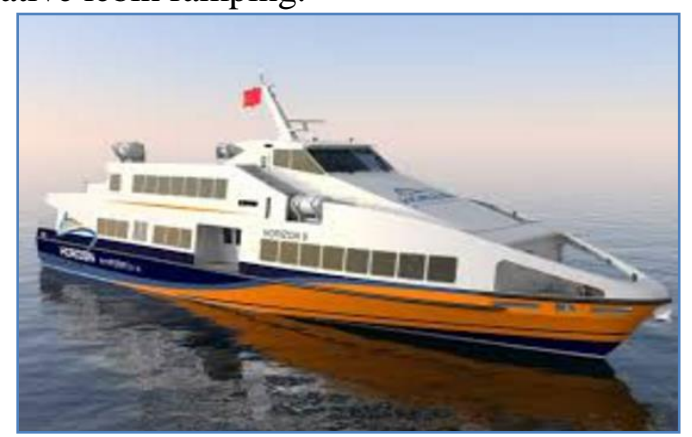

Gambar 4. Kapal Fast Ferry

Metode Kapal Pembanding dapat digunakan untuk menentukan ukuran utama kapal dengan 
bantuan kapal pembanding [3]. Dibutuhkan beberapa data kapal pembanding yang memiliki kriteria umum yang sama seperti kapal yang akan dirancang dengan menentukan ukuran utamanya. Adapun preliminary desain yang terpenting adalah kapal yang akan dirancang ditentukan ukuran utamanya [7]. Kapal pembanding yang digunakan untuk memecahkan masalah ini adalah memilki tipe jenis kapal yang sama, dan memilki kriteria seperti ukuran payload yang tidak terlalu jauh berbeda. Bentuk kapal cepat dapat diberikan oleh sejumlah parameter, yang dihubungkan dengan parameter desain yang biasa diterapkan selanjutnya untuk rencana garis [4].

Banyak faktor - faktor tentang hubungan antara DWT dan dimensi kapal. Dimensi kapal ferry dan kapal RO-RO misalnya, mempunyai dimensi dan ukuran yang berbeda. Kapal RO-RO mempunyai dimensi yang lebih besar dengan lambung yang besar, dimana dimensi dan tipe bentuk lambung depan kapal agak melebar, berbeda dengan kapal ferry yang lebih ramping dimensi dan tipenya berhubungan [5]. Besanya DWT meruoakan komponen berat kapal yang dapat dipindahkan dalam satuan ton. Sedangkan besarnya DWT dapat diketahui dari rumus:

$$
\mathrm{DWT}=\Delta-\mathrm{LWT}
$$

Dimana DWT adalah muatan kapal yang dapat dipindahkan dalam ton, $\Delta$ atau displacement adalah muatan air laut yang dipindahkan dalam ton, sedangkan LWT adalah muatan tetap kapal dalam ton.

Pada regresi linier menggunakan metode regresi kuadrat terkecil [8]. Dimana regresi kuadrat terkecil adalah suatu regresi dengan kontrainnya adalah jumlah kuadrat jarak vertikal setiap titik dalam data terhadap kurva regresi menjadi minimum. Dalam analisis numerik kuadrat regresi yang lebih dikenal dengan nama Least-Squares Method [9], merupakan salah satuan metode pendekatan yang paling penting dalam dunia keteknikan untuk :

(a.) Penentuan regresi ataupun pembentukan persamaan dari titik data diskretnya (dalam pemodelan), dan

(b.) Proses analisis sesatan pengukuran (dalam validasi model).

Metode kuadrat terkecil yang dijabarkan oleh Atkinson, L.V. [2], termasuk dalam keluarga metode-metode pendekatan sesatan terdistribusi

("distributed eror'approximation methods), berdasarkan karakteristik kerjanya yang dapat melakukan pengurangan sesatan menyeluruh (global eror) yang terukur berdasarkan interval pendekatan keseluruhan (whole approximation interval) sesuai dengan order pendekatan yang meningkat. Metode kuadrat terkecil ini juga memainkan peranan penting dalam analisis numerik karena metode ini seringkali digunakan penyelesaian problem-problem yang melibatkan kumpulan data yang tersusun secara acak [1].

Dalam buku Practical ship design, beberapa dasar teori dalam proses perencanaan bentuk lambung kapal [10]. Rencana garis telah banyak dijelaskan antara lain dengan metode dari Scheltema, NSP, Ship geometri dan lain-lain.

\section{METODE}

\subsection{Tahapan Perancangan}

Tahapan Perancangan sesuai dengan diagram alir dibawah ini

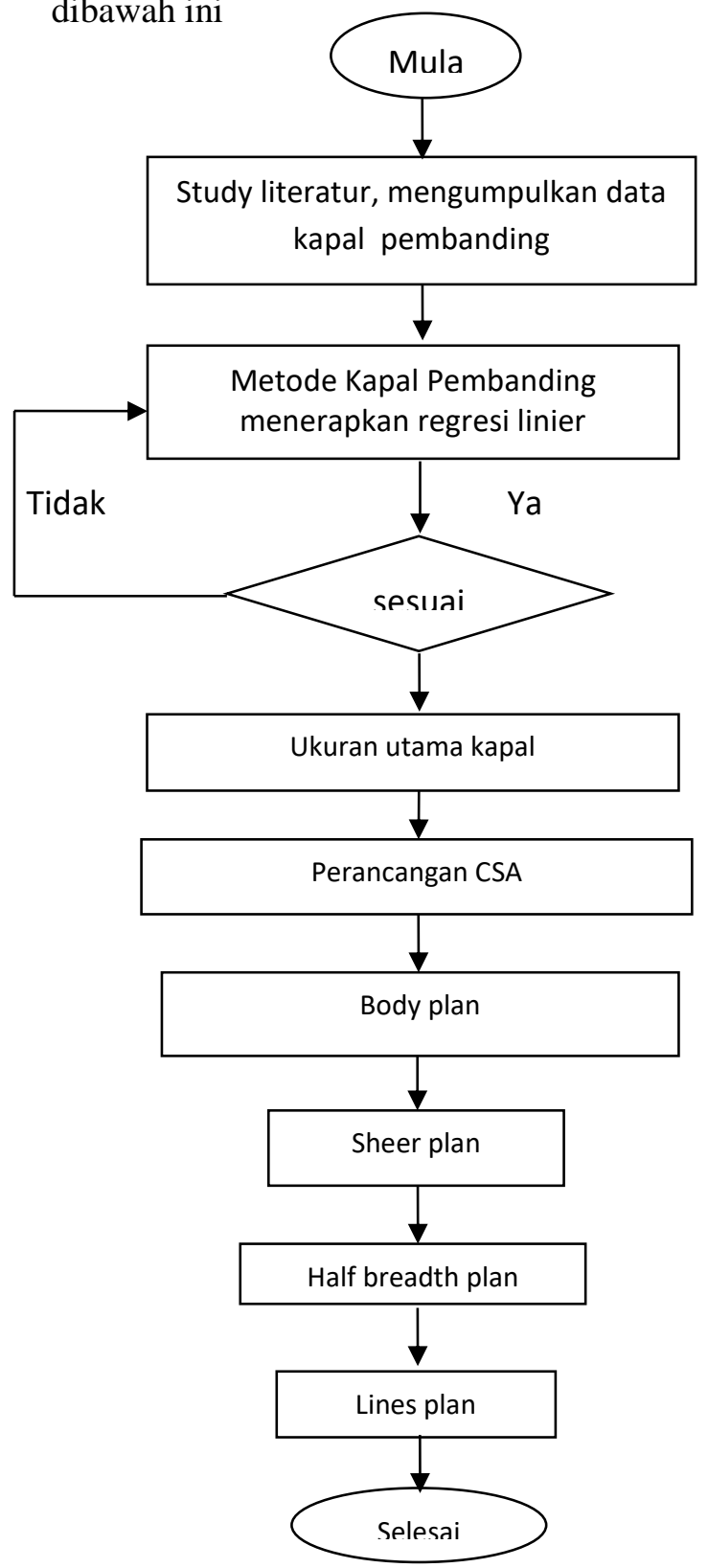

Gambar 5. Flowchart tahapan - tahapan desain 


\subsection{Analisis Kebutuhan Desain}

Tahapan - tahapan desain yang digambarkan dalam bentuk flowchart bertujuan untuk mengetahui metode apa yang digunakan dalam perancangan kapal fast ferry 150 Pax ini. Tiap Metode dalam flowchart dapat dijelaskan sebagai berikut:

2.2.1 Study Literatur kapal fast ferry dan mengumpulkan data ukuran utama kapal.

Study literatur adalah pengumpulan referensi yang bertujuan untuk memperkuat database penegtahuan serta menggali lebih dalam informasi mengenai perancangan kapal fast ferry 150 pax ini. Study literatur dapat diperoleh melalui buku atau dari internet. Dalam hal ini dibutuhkan referensi yang relevan mengenai kapal ferry dan mengumpulkan ukuran utama yang sejenis dengan kapal fast ferry

\subsubsection{Penentuan ukuran utama kapal.}

Setelah melakukan studi literatur yang relevan, selanjutnya adalah penentuan ukuran dimana didapatkan dari proses regresi linier dari kapal pembanding.

\subsubsection{Ukuran utama kapal fast ferry 150 pax.}

Didapatakan ukuran kapal fast ferry dengan optimasi regresi linier yang dihasilkan dari kapal pembanding. Sehingga kapal fast ferry dapat ditentukan ukuran utamanya.

\subsubsection{Perancangan CSA}

CSA (Cross Section Area) merupakan luasan penampang menimpang kapal tiap station yang fungsinya, dapat digunakan untuk menentukan bentuk body plan kapal. Dimana dalam hal ini penentuan CSA dapat dicari berdasarkan kurva bisa dari metode scheltema, NSP, Hamlin, dsb.

\subsubsection{Body plan}

Body plan merupakan kumpulan dari stationstation penampang kapal yang merupakan representasi bentuk lambung kapal.

\subsubsection{Sheer Plan}

Potongan bentuk lambung kapal berdasarkan buttock plan atau potongan secara memanjang kapal berdasarkan jarak BL secara memanjang kapal.

\subsubsection{Half breadth Plan}

Potongan bentuk lambung kapal berdasarkan Water line atau potongan secara horizontal kapal berdasarkan jarak WL secara horizontal kapal.

\subsubsection{Lines Plan}

Sisi luar lambung kapal berbentuk lengkung, dimana pada beberapa kasus terdapat tekukan, lengkungan dan penggambaran lambung kapal pada sebidang kertas gambar yang dinamakan rencana garis (lines plan/ship's lines/ lines),

\subsection{Piranti pendukung perancangan a. Perangkat Keras (Hardware)}

Dalam kebutuhan perangkat keras untuk menunjang running perancangan desain kapal Fast Ferry 150 Pax maka dibutuhkan sebuah perangkat keras yaitu:

a. Laptop dengan processor minimal dual core dan memory $3 \mathrm{~GB}$

b. Portable hardisk 2 tB untuk proses design CAD

\section{b. Perangkat Lunak (Software)}

Dalam suatu perancangan kapal Fast Ferry 150 Pax yang digunakan saat melakukan perhitungan design kapal membutuhkan suatu software guna menunjang sistem tersebut adapun software yang dibutuhkan antara lain
a. AutoCad
b. MS Excell

\subsection{Desain dan Perencanaan}

Desain kapal Fast Ferry 150 Pax yang akan dikerjakan ini, seperti pada gambar 6 blok diagram Perencanaan kapal sebagai berikut:

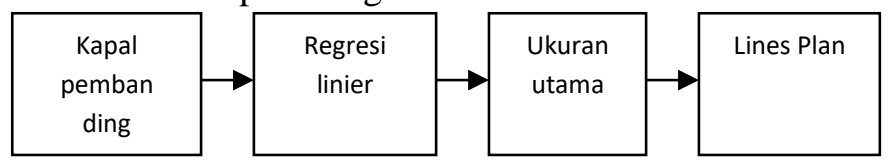

Gambar 6 Blok Diagram Perencanaan kapal

\section{HASIL DAN PEMBAHASAN}

\subsection{Perancangan ukuran utama kapal}

Metode Kapal Pembanding dapat digunakan untuk menentukan ukuran utama kapal fast ferry 150 Pax dengan bantuan kapal pembanding, dibutuhkan beberapa data kapal pembanding yang memiliki kriteria umum yang sama seperti kapal yang akan dirancang dengan menentukan ukuran utamanya. Dengan langkah awal melakukan pengumpulan data kapal pembanding yang sejenis dengan menempatkan beberapa focus pada DWT, NT,GT, LOA, LPP,B,H,T, dan V kapal. komponen ukuran utama tersebut perlu karena merupakan komponen yang akan didapatkan untuk memperoleh kompenen ukuran utama yang direncanakan untuk kapal Fast 
Ferry 150 Pax. Adapun bentuk tabulasi ukuran utama dapat ditunjukan pada tabel berikut:

Tabel 1. Tabel ukuran utama kapal existing

\begin{tabular}{|c|c|c|c|c|c|}
\hline $\begin{array}{l}\text { Nama } \\
\text { Kapal }\end{array}$ & $\begin{array}{c}\text { Niga } \\
\text { Ferry } \\
-16\end{array}$ & $\begin{array}{c}\text { SL } \\
\text { Tagka }\end{array}$ & Slavent & $\begin{array}{l}\mathrm{M} / \mathrm{V} \mathrm{K} \\
\text { Peraltos }\end{array}$ & Manjaro \\
\hline DWT & 150 & 181 & 129 & 156 & 156 \\
\hline NT & 160 & 220 & 150 & 225 & 225 \\
\hline GT & 420 & 420 & 390 & 250 & 250 \\
\hline Loa & 34 & 34 & 31.3 & 35 & 33.8 \\
\hline LBP & 32 & 31 & 30.5 & 33 & 30.4 \\
\hline B & 5.4 & 4.8 & 4.76 & 5.1 & 4.9 \\
\hline $\mathrm{H}$ & 1.75 & 1.8 & 1.9 & 1.8 & 1.8 \\
\hline $\mathrm{T}$ & 1 & 1 & 1 & 1 & 0.8 \\
\hline $\mathrm{V}$ & 27 & 26 & 25 & 30 & 28 \\
\hline
\end{tabular}

Hasil formula regresi linier:

\begin{tabular}{ll}
\hline GT - LBP & \\
\hline $\mathrm{m}=$ & 0.0832 \\
$\mathrm{~b}=$ & 0.81348 \\
$\mathrm{y}=$ & $0.0832 \mathrm{X}+0.8135$ \\
Harga LBP [ $\mathrm{m}]$ & \\
400 & 33.09 \\
\hline & \\
\hline GT $-\mathbf{B}$ & \\
\hline $\mathrm{m}=$ & 0.0134 \\
$\mathrm{~b}=$ & 0.1384 \\
$\mathrm{y}=$ & $0.0134 \mathrm{X}+0.1384$ \\
Harga B [ $\mathrm{m}]$ & \\
400 & 5.50 \\
\hline & \\
\hline GT $-\mathbf{H}$ & \\
\hline $\mathrm{m}=$ & 0.0049 \\
$\mathrm{~b}=$ & 0.0558 \\
$\mathrm{y}=$ & $0.0049 \mathrm{X}+0.0558$ \\
Harga H [ m ] & \\
400 & 2.00 \\
\hline & \\
\hline GT - T & \\
\hline $\mathrm{m}=$ & 0.0026 \\
$\mathrm{~b}=$ & 0.0225 \\
$\mathrm{y}=$ & $0.0026 \mathrm{X}+0.0225$ \\
Harga T [ m ] & \\
400 & 1.08 \\
\hline &
\end{tabular}

\begin{tabular}{ll}
\hline GT - DWT & \\
\hline $\mathrm{m}=$ & 0.41718 \\
$\mathrm{~b}=$ & 4.5320 \\
$\mathrm{y}=$ & $0.4172 \times 4.5320$ \\
Harga B [m] & \\
400 & 171.40 \\
\hline
\end{tabular}

Dari hasil regresi linier diatas didapatkan variable ukuran utama yang dibutuhkan dalam membuat desain rencana garis. Selanjutnya dapat dikembangkan perancangan ukuran utama dari hasil regresi linier Fast Ferry 150 Pax. Didapatkan ukuran utama kapal sebagai berikut:

$\begin{array}{llll}\text { Loa } & : & 35.00 & \mathrm{~m} \\ \text { LPP } & : & 33.09 & \mathrm{~m} \\ \text { Breadth } & : & 5.50 & \mathrm{~m} \\ \text { Depth } & : & 2.00 & \mathrm{~m} \\ \text { Draft } & : & 1.08 & \mathrm{~m} \\ \text { Direncanakan } & & & \\ \text { Vs } & : & 30 & \text { knots }\end{array}$

\subsection{Perancangan CSA}

Curve of Sectional Area (CSA) merupakan kurva yang menunjukan luasan kapal pada tiap station. Luasan tiap station didapatkan dari gambar diagram Sceltema atau Hamlin ataupun NSP. pada metode NSP dengan cara mencari nilai $\mathrm{Vs} / \sqrt{ }$ Ldisp terlebih dahulu kemudian membuat garis horisontal dari nilai yang didapatkan, pada garis horizontal tesebut akan didapatkan perpotongan garis dengan tiap station kemudian dari titik potong ditarik garis vertikal ke atas dan ditemukan nilai prosentase tiap station. Kemudian dikembangkan menjadi CSA. Dimana pada gambar CSA diberikan nilai tiap luasan untuk membetuk kurva CSA. Disamping juga melakukan koreksi volume displacement dan letak LCB sehingga didapatkan desain CSA yang baik dan streamline.Adapun gambar 7 CSA ditunjukan pada gambar dibawah ini:

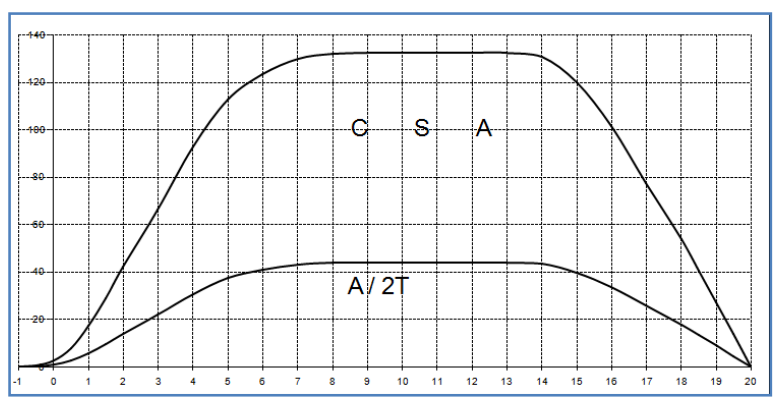

Gambar 7. Gambar CSA

\subsection{Rencana Garis}

Rencana garis merupakan representasi dari bentuk lambung. dimana dapat dibentuk rencana garis berdasarkan frame spacing atau jarak gading. Frame spacing kapal ini adalah $0.6 \mathrm{~m}$. berikut ditunjukan gambar 8 rencana garis. 


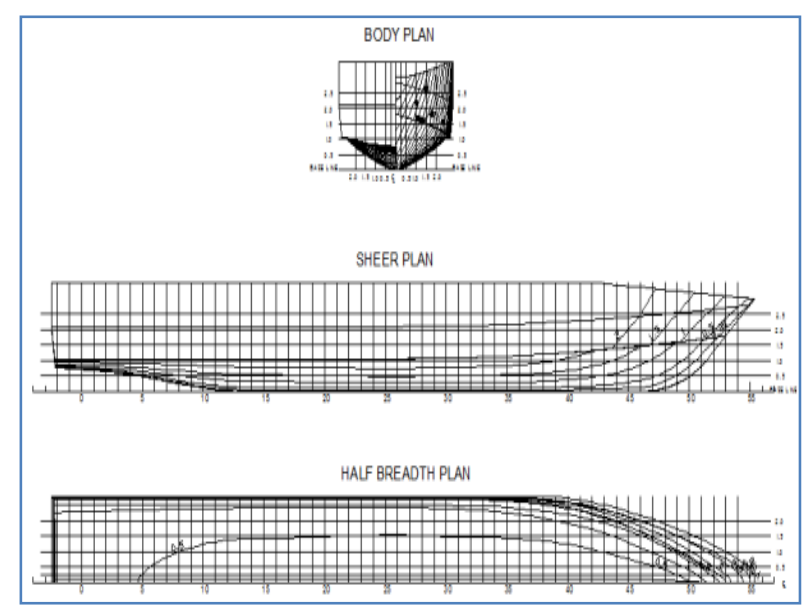

Gambar 8. Rencana garis

Body plan merupakan kumpulan dari stationstation penampang kapal yang merupakan representasi bentuk lambung kapal. Sheer Plan merupakan potongan bentuk lambung kapal berdasarkan buttock plan berjarak $0.5 \mathrm{~m}$ atau potongan secara memanjang kapal berdasarkan jarak BL berjarak $0.5 \mathrm{~m}$ secara memanjang kapal. Half breadth Plan Potongan bentuk lambung kapal berdasarkan Water line berjarak $0.5 \mathrm{~m}$ atau potongan secara horizontal kapal berdasarkan WL berjarak $0.5 \mathrm{~m}$ secara horizontal kapal.

\section{KESIMPULAN}

Setelah melakukan perancangan, didapatkan ukuran utama kapal Fast Ferry 150 Pax yang ditunjukan sebagai berikut:

$\begin{array}{llll}\text { Loa } & : & 35.00 & \mathrm{~m} \\ \text { Breadth } & : & 5.50 & \mathrm{~m} \\ \text { Draft } & : & 1.08 & \mathrm{~m} \\ \text { Depth } & : & 2.00 & \mathrm{~m} \\ \text { Vs } & : & 30 & \mathrm{kts} \\ \text { DWT } & : & 172 & \text { ton } \\ \text { Cb } & : & 0.7 & \end{array}$

Perlu dikembangkan mendesain tingkat lanjut rencana umum dan detail kapal, dengan memasukan faktor - faktor yang mempengaruhi, baik dari segi analisis bentuk lambung kapal.

\section{UCAPAN TERIMA KASIH}

Ucapan terima kasih diberikan kepada Bpk. Ir. Muryadin M.Sc, yang membantu dan memberi masukan terhadap data-data penelitian.

\section{DAFTAR PUSTAKA}

[1] Atkinson, Kendal E., "An Introduction to Numerical Analysis", John Wiley \& Sons, Toronto, pp. 44-48, 1978.

[2] Atkinson, L.V., Harley, P.J., "An Introduction to Numerical Methods with Pascal", AddisonWesley Publishing Co., Tokyo, pp. 49-51, 1983.

[3] Cohen, T., et al. " Comparison of physical and numerical ship modelling" Research. CRD Press, 2013. 398-403.

[4] Harries, Stefan, et al. "Investigation on optimization strategies for the hydrodynamic design of fast ferries." 6th International Conference on Fast Sea Transportation, Southampton. 2001.

[5] Kendall, P. M. H. "A theory of optimum ship size." Journal of Transport Economics and Policy (1972): 128-146

[6] Keuning, Jan Alexander. "Fast ship." U.S. Patent No. 9,359,048. 7 Jun. 2016.

[7] Kuiper, G. "Preliminary design of ship lines by mathematical methods." Journal of ship Research 14. 1, 1970.

[8] Marquardt, Donald W. "An algorithm for least-squares estimation of nonlinear parameters." Journal of the society for Industrial and Applied, 2002.

[9] Peduzzi, Peter, et al. "A simulation study of the number of events per variable in logistic regression analysis." Journal of clinical epidemiology 49.12 (1996): 1373-1379. Mathematics 11.2 (1963): 431-441.

[10] Watson, David GM. Practical ship design. Vol. 1. Gulf Professional Publishing, 2002. 